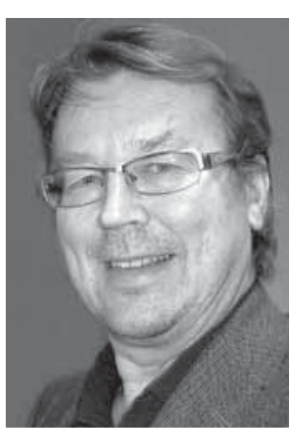

P̈̈ÄKIRJOITUS

\title{
OPETTAMISEN JA OPPIMISEN SUKUPUOLI
}

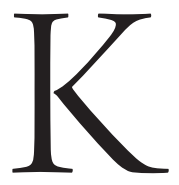

oulutus on vahvasti eriytynyt sukupuolen mukaan. Perusasteelta lähtien tytöt pärjäävät koulussa poikia paremmin. Sukupuolten väliset osaamiserot ovat tuttuja monissa maissa, kuten PISA-arvioinnit osoittavat, mutta meillä ero on monessa aineessa huomattavan suuri. Tytöt saavat kouluopetuksesta enemmän irti kuin pojat. Tai ehkä pojat oppivat kouluaikana jotain muuta kuin mitä opetussuunnitelmiin on kirjoitettu. Kysymys on tyttö- ja poikakulttuurien osumisesta yksiin koulukulttuurin kanssa. Asian tiedostamisesta huolimatta kouluinstituutio ei ole onnistunut sulkemaan pois sukupuolistereotypioita ja niihin perustuvia mies- ja naismalleja, joiden vaikutuksille kouluikäiset ovat erityisen alttiitta. Isien esimerkki on pojille tärkeä. Tätä nykyähän miehet käyttävät esimerkiksi kirjastojen palveluja selvästi vähemmän kuin naiset. Lapset tutustuvat kirjaan useimmiten äidin välityksellä.

Oppimistulosten erot jatkuvat lukiossa, jonka oppilaat ovat jo pitkään olleet valtaosaltaan tyttöjä. Vaikka lukioon etenevät pojat ovat selvästi valikoituneempia kuin tytöt, tytöt pärjäävät lukiossakin poikia paremmin. Vuoden 2008 tietojen mukaan 23 prosenttia naisista ja 11 prosenttia miehistä sai ylioppilastutkinnon äidinkielen kokeesta arvosanan eximia tai laudatur. Miehistä 35 prosenttia ylsi äidinkielessä korkeintaan lubenterin arvosanaan (naisista vastaavasti 17 prosenttia).

AMMATILLISESSA KOULUTUKSESSA, ammattikorkeakouluissa ja yliopistoissa suuri osa koulutuksesta on eriytynyt miesten ja naisten aloihin. Naisvaltaisimpia aloja ovat suuri sosiaali-, terveys- ja liikunta-ala (opiskelijoista 86 prosenttia naisia ), humanistinen ja kasvatusala sekä matkailu-, ravitsemisja talousala (opiskelijoista lähes 80 prosenttia naisia). Toisella laidalla ovat tekniikan ja liikenteen ala, jolla opiskelevista yli 80 prosenttia on miehiä. Alojen eriytyminen heijastaa työelämän segregoitumista. Työelämässä taas asemat, valta ja tulot jakautuvat epätasaisesti miesten ja naisten kesken. Maisterin tutkintoon yltävä nainen hyötyy noin 20-vuotisesta koulutusinvestoinnistaan selvästi maisterismiestä vähemmän.

OECD:n viimevuotisesta Education at a Glance -raportista voimme lukea, että suomalainen yhteiskunta "hyötyy" miehen korkeakoulututkinnosta 84400 euroa (OECD-maiden keskiarvo on 67800 euroa). Sen sijaan naisen korkeakoulutuksesta yhteiskunta hyötyy vain 32700 euroa (OECD:n keskiarvo 41200 euroa). Toisaalla esimerkiksi Portugalin 
"TYÖEL ̈̈MÄSS ̈̈ ASEMAT, VALTA JA TULOT

JAKAUTUVAT EPÄTASAISESTI MIESTEN JA NAISTEN KESKEN.

MAISTERIN TUTKINTOON YLTÄVÄ NAINEN HYÖTYY

NOIN 2O-VUOTISESTA KOULUTUSINVESTOINNISTAAN

MAISTERISMIEST $\ddot{A}$ VÄHEMMÄN.”

ja Turkin yhteiskunnat saavat naisen korkeakoulutuksesta suuremman hyödyn kuin miesten. Maiden väliset erot koulutuksen hyödyissä ovat suuret. Koulutuksen yhteiskunnallisten hyötyjen laskelmassa menoihin luetaan koulutuksen aikaiset verotulon menetykset, sosiaaliset tuet ja koulutuksen julkiset menot. Tuloiksi luetaan suuremmista ansiotuloista maksettavat verot sekä säästöt sosiaalisten tukien kustannuksissa.

OPETTAMINEN ON KAIKKIALLA Euroopassa naisenemmistöinen ala. Hallinto- ja johtopaikat ovat kuitenkin miesten hallussa. Eurydice-raportin (Gender differences in educational outcomes) mukaan Suomessa ala-asteen rehtoreista 62 prosenttia ja yläasteen rehtoreista 58 prosenttia on miehiä. Vähemmän naisrehtoreita on vain Kreikassa ja Hollannissa. Miesrehtori johtamassa naisista koostuvaa opettajakuntaa on huomionarvoinen osa koulujen piiloopetussuunnitelmaa.

Vuodelta 2009 olevien tietojen mukaan Opetus- ja kulttuuriminieriön ministeriön virkamiehistä 69 prosenttia on naisia. Mutta ministeriön naisia on aina johtanut kansliapäällikkönä mies.

ON VÄLILlÄ AIHEELlista suhteuttaa Suomen tilastotietoja koko maailman väestöä kuvaaviin lukuihin. Nimittäin vain kolmasosassa maailman maita tyttöjen osuus koulussa yltää poikien osuuden tasolle. Ja mitä korkeammalle oppilaitoshierarkiassa mennään, sitä vähäisemmäksi käy tyttöjen ja naisten osuus. Heikoimmin kouluun pääsevät maaseudun köyhät, alkuperäiskansat ja muut vähemmistöt sekä vammaiset. Näissä väestöryhmissä ja kehitysmaissa yleensä kaikkein heikoimmassa asemassa ovat tytöt. Joka viides aikuinen eli lähes 800 miljoonaa ihmistä maailmassa ei osaa lukea. Kaksi kolmasosaa lukutaidottomista on naisia. Sukupuolenmukaisessa työnjaossa kotityöt lankeavat useimmissa kulttuureissa kuin itsestään selvyytenä tytöille, minkä vuoksi köyhät perheet eivät pidä tyttöjen lähettämistä kouluun yhtä tärkeänä kuin poikien. Tyttöjen työvoimaa tarvitaan kotona. Monissa maissa tytöt ja naiset huolehtivat maanviljelystä, keräävät polttopuut, hoitavat lapset, valmistavat ruoan ja palvelevat miestä perheen päänä. Koko maailman mittakaavassa naiset tekevät miehiä enemmän työtunteja, mutta joutuvat tyytymään kymmenesosaan kaikista tuloista - eivätkä omista juuri mitään.

Tyttöjen kouluttaminen vaikuttaa monin tavoin myös välillisesti. Kouluja käymällä naiset pääsevät palkkatyöhön ja käyttävät tulonsa koko perheen hyvinvointiin. Koulutetut tytöt osaavat paremmin huolehtia itsestään ja perheistään, eivätkä ole riippuvaisia miehestä perheen elättäjänä. He avioituvat myöhemmin ja hankkivat vähemmän lapsia kuin kouluttamattomat. Koulutusta saaneet naiset lähettävät myös omat tyttärensä kouluun.

Heikki Silvennoinen 